\title{
Law New and Old: Tropes of Blindness in the Celestina
}

\author{
Marlen Bidwell-Steiner \\ Universität Wien
}

\begin{abstract}
This article traces juridical elements in the monologues of Melibea, Calisto and Pleberio in order to elaborate on the negotiations between old and new law and-on an allegorical level-old and re/new/ed faith as major topics of the tragicomedia. In a further step, I will connect this text-based analysis to the material culture of the early book in Spain, insofar as the production of printing shops in Salamanca and Burgos evidences a variety of texts with a similar preoccupation for legal reforms. This reveals the embeddedness of the Celestina in a network of European humanism. The re-occurrence of blind Justice as a key trope in such contemporaneous texts helps to trace some of its discursive purposes. Combining these different perspectives could shed new light on discussions about the enigmatic creation of the Celestina by reconciling different approaches.
\end{abstract}

Key words: Celestina, law, allegory, Badius, Piccolomini, Nebrija, Cisneros.

\section{Ley nueva, ley antigua: tropos de ceguera en la Celestina}

\section{RESUMEN}

El presente artículo indaga elementos jurídicos en los monólogos de Melibea, Calisto y Pleberio para elaborar en las negociaciones entre ley antigua y ley nueva - y en un nivel alegórico - entre fe antigua y fe renovada como temas centrales de la tragicomedia. En un segundo paso, este analisis textual se relaciona a la cultura material de los incunabula en España. Señaladamente, la producción en las editorales de Salamanca y Burgos evidencia una acumulación de textos que se dedican a reformas jurídicas. Eso revela que la Celestina se arraiga en una red del humanismo europeo. El enfoque en el recurrente tropo de la Justicia ciega en estos textos pretende seguir la intención de la obra. La combinación de estas distintas perspectivas deja revisar el enigma de la creación de la Celestina a partir de reconciliar distintas perspectivas de investigación.

Palabras Clave: Celestina, derecho, alegorias, Badius, Piccolomini, Nebrija, Cisneros. 
One of the most prolific subjects in European literature is the entanglement of love and crime, as enacted in the Celestina so virtuously. To untangle its narrative threads remains a fascinating task, despite or even due to a myriad of sophisticated propositions. One of the less featured approaches is the investigation of casuistic speech in the Celestina. On the threshold between the Middle Ages and Renaissance, casuistry becomes a "method of mind» (Sullivan 1976: 51) that informs both penitential purification and worldly justice. Especially fruitful is the investigation of legal casuistry in the Celestina. ${ }^{1}$ In this article, the focus will lie on its merging with allegorical figures in the speech acts of Calisto, Melibea and Pleberio.

The Celestina is an ideal case in point for tracing the knowledge transfer of legal discourse into imaginative literature, if we proceed from José Luis Canet's claim that the text clearly echoes the disputations of law students and jurists like Fernando de Rojas himself-that is to say, an academic circle familiar with utrumque ius (cf. Canet 2008, 2017). This is all the more important since at the time when the Celestina was created, the structures of church, university and courts experienced a considerable re-organization. To map the gap between the polysemy of the original text and the more rigorous tendencies in later Counter-Reformation Spain, I will consult the glosses of the Celestina comentada for the analysis of representative passages. ${ }^{2}$

Obviously, the abundance of vices performed by Celestina's different protagonists offers a vast field of investigation regarding juristic discourse. ${ }^{3}$ Nearly all capital sins are present. Moreover, the text is very explicit about the circumstances of the offences-a key element for judging their severity. An equally important feature for deciding a verdict is the offender's intention. Quite remarkable for a text in dramatic mode, the Celestina also provides for such insights in the protagonists' self-assessment-namely, soliloquies and monologues performed by the central couple, Calisto and Melibea, and by Pleberio, Melibea's father.

In this article, I will concentrate on the rhetorical elaborations at the intersection of the last two of these speech acts: Melibea's monologue and following confession to her father and Pleberio's subsequent lament over her suicide. Tracing casuistic elements in their orations will elucidate references to old and new law and (on an allegorical level) old and new faith.

In a further step, this text-based analysis will then be linked to the market conditions of the incunabula, thereby revealing an amazing network of European humanists who shared similar ideas, agitations and prob-

1.- The promising endeavour of confronting the tragi/comedia with confessionals I will undertake in a separate article.

2.- I would like to express my gratitude for this suggestion to the anonymous reader of the first version of this article.

3.- To consult a very interesting and representative text in this field, see Iglesias 2015. 
lems and whose interactions superseded national and linguistic boundaries. I will suggest that the re-occurrence of Justice as a key trope in such contemporaneous texts sheds light on its discursive purpose. Bringing together the analysis of text passages with the material history of the printed book, iconography and the history of ideas shall contribute to unravel the enigmatic creation of the Celestina and thereby reconcile different strands within the research of this literary masterpiece. ${ }^{4}$

\section{Eloquent death drive}

One of the most disturbing elements of the Celestina is the grandiloquent staging of Melibea's suicide. As an almost proto-romantic heroine, she praises her cowardly and quite un-courtly lover, the "obsede ridicule» Calisto $^{5}$, as irreproachable-instead accusing herself of the shame and dishonor she brings to her parents. Yet her acknowledgement of guilt reads as quite ambivalent: «Tú, Señor, que de mi habla eres testigo, ves mi poco poder, ves cuán cautiva tengo mi libertad [...]» (Rojas 2011: 331). What might be understood as diminished capacity due to a libre albedrio corrupted by passion is framed in two contradictory passages: at the beginning of her monologue Melibea clarifies that her trespass happened out of free will: «Todo se ha hecho a mi voluntad» (Rojas 2011: 329). She then proceeds to rationalize the vices she committed by contrasting (and thereby downplaying) them with a feisty digression into the most abominable figures of classical history such as Nero, to conclude: «Éstos son dignos de culpa, éstos son verdaderos parricidas, que no yo [...]» (Rojas 2011: 331).

At the end of this inconsistent confession to her father she recommends her soul to God, although she ends with a prolepsis of her suicide: «Dios quede contigo y con ella. A él ofrezco mi alma. Pon tú en cobro este cuerpo que allá baja» (Rojas 2011: 335). And in fact, she immediately afterwards plunges herself from the lofty tower. This act represents nothing less than one of the few inexcusable sins in Catholic terms, excluded from penitential practices by its very nature. A case that even according to the anonymous author of the Celestina comentada needs no extensive explanation. His relatively short gloss of this passage states at the end: «Demas de esto el que se mata a si mesmo contra el precepto divino haze que manda 'no mataras' a que no solo de otra persona pero de si mismo se entiende" (CC 2002: 499). As Eukene Lacarra points out, in early modern Spain suicide entailed not only loss of honor but also sanctions on

4.- For an overview on the question of authorship and editorial history of the text see Serés 2011: 361-401.

5.- This is an accurate notion coined by Bataillon 1961:109, whose reading of the Celestina as an exclusively moralizing text I do not share without reserve. 
the suicide's family (cf. Lacarra 2007). Classifying her deed as sparing her parents from further social blame would therefore be virtually impossible. But if we interpret the text as an academic competition in a forensic debate, its semantics become quite different.

In my view, the tradition of the medieval quodlibet as practiced in law schools can be regarded as a precursor of early modern probabilistic casuistry for taking into account even far-fetched argumentations. From this vantage point, Melibea's suicide could be read as a restoration of her father's honor. What allows for such a daring view is a famous female exemplum in Giovanni Boccaccio's Claris mulieribus, Lucretia. "[T] he Lucretia story aims to create a conscience that makes a woman consider herself unworthy of living once her pudicitia is infringed", notes Nikolaus Benke in explaining the significance of the narration within the system of classical patria potestas (Benke 2012: 290).

In this context, the signification of Melibea's death shifts into an ironic misrepresentation of "acceptable» female suicide. This reading is further corroborated by the fact that it is her servant Lucrecia who accompanies the protagonist until her very end. And there is another famous Lucretia who became a victim of love, the protagonist of the Historia de duobus amantibus, one of the identified sources of the Celestina (cf. Ravasini 2003, Matos 2018). This (married) female trespasser suffers from a more decent death, gradually languishing away. In the eyes of contemporaneous audiences outside the university, such a solution of poetic justice most certainly would also have better suited our maiden Melibea. As Lacarra further states, some of the church fathers inveighed against the suicide of young women losing their virginity (Lacarra 2007: 176); one of them was Augustine, to whom I will later refer.

\section{Condensed allegories}

Obviously, Pleberio does not consider his daughter's deed as a sacrifice, but rather as an incomprehensible blow of fate: « $\mathrm{O}$ h fortuna variable, ministra y mayordoma de los temporales bienes!» (Rojas 2011: 339). His lament conspicuously switches addressees from daughter and wife to deity, and develops a discourse of what I would like to call condensed tropology. With due caution against anachronistic theorizing, the psychoanalytical concept of Verdichtung (condensation) proofs to be helpful for analyzing the rhetoric of the following passage: Freud (1990: 49) argues that the conflation of different symbolic elements into one master trope is overcharged with semantic value, such as blindness in our text: Pleberio explicitly invokes allegories of mad love, fortune, and justice-personae who interact in blinding, or at least misleading, the young couple. And strangely enough, all these tropes appear blindfolded, as we shall see. 
Immediately after "responding» to dead Melibea, Pleberio refers to the Roman goddess Fortuna whom he blames for his universal loss: «iPor qué no destruiste mi patrimonio? [...] Dejárasme aquella florida planta en quien tú poder no tenías. Diérasme, fortuna flutuosa, triste la mocedad con vejez alegre; no pervertieras la orden» (Rojas 2011: 339).

This is an interesting twist, since apart from the blindfold, Fortuna's attribute is a wheel, a representation quite similar to a clock. And in fact, the clash between time and order is a prominent topic of the overall narrative, which on different levels indicates a rupture of value and organization systems: old law versus new law, old faiths versus (re)new(ed) faith.

After his lament on the vicissitudes of Fortune, Melibea's father, conspicuously echoes a complaint of his "adversaries», Celestina and Calisto: "[...] inicua es la ley que a todos igual no es» (Rojas 2011: 344). Yet the rules Pleberio is objecting do not belong to the court of law but to a different court, Amor's ploys: «Dios te llamaron otros, no sé con qué error de su sentido traídos. Cata que Dios mata los que crió; tú matas los que te siguen. [...] Ciego te pintan, pobre y mozo» (Rojas 2011: 345).

Here blindness is even mentioned explicitly. One of the first scholars to elaborate on blind Eros is the art historian Ernst Panofsky. He relates the advent of Amor's pictorial attribute with the clash of two Christian concepts of love: caritas and cupiditas, i.e., charity versus cupidity. While medieval courtly love offered a model for reconciling this antithesis in a sort of education program for young courtiers, the tension returns in the fourteenth century, when parts of the feudal order were superseded by an ever more urban society in which amor functioned as a commodity. In such an environment-which corresponds to the setting of the Celestina - the depiction of Eros or Cupid as a young boy changes: apart from his classical attributes, the arrow and torch, from the $14^{\text {th }}$ century on Eros is blindfolded - thus representing unruly love (Panofsky 1982: 110 sig.).

But Panofsky's reconstruction of this late medieval «moralizing mythography» (Panofsky 1982: 104) does not stop here. He relates this iconography of mad love to other representations of iconographical blindness: "Blind Cupid started his career in rather terrifying company: he belonged to Night, Synagogue, Infidelity, Death and Fortune who had also joined the group of blindfold personifications» (Panofsky 1982: 112). Panofsky introduces this register of blind personae to corroborate his claim that iconographical blindness in medieval art indicates misbelief and annihilation. This is quite remarkable in the context of Celesti$n a$, since the text exhibits some of the disagreeable "consorts» of blind Cupid. As already mentioned, Melibea's suicide before daybreak elicits Pleberio's lament on the vagaries of Fortune; thus, Amor, Death, Fortune, Night and arguably Infidelity between daughter and father appear to be conflated in emblematic blindness. Yet, in Panofsky's list of blind personae 
there is the somewhat surprising presence of Synagogue and the no less surprising absence of Justitia.

\section{The case of Justitia}

One could argue that the latter is a positive allegory and therefore evidently not related to such representations of loss. Furthermore, Panofsky links justice's blindfold to a different and later development of mistrust in human righteousness. But given the convergence of fortune, (mad) love, and justice in Pleberio's monologue and the recurrent claim of justice's iniquity in the overall plot of the Celestina, there seems to be a missing link. And in truth, it is somehow disappointing that Panofsky does not further investigate the impact of what he himself identifies as the first appearance of the young maiden with sword, scale and blindfold: Sebastian Brant's Narrenschiff from 1494. In this almost contemporaneous text of another - this time Northern - jurist, it is a fool who blinds justice. The poem accompanying Albrecht Dürer's woodcut clearly refers to the insanity of court litigations where a group of lawyers is blinding the truth with endless sophistications (Brant 1968: 258). This seems to corroborate Panofsky's conviction that Justice's blindfold as a positive trait is of a later iconography.

Yet a closer look at the pictorial program links Dürer's depiction of Justice in the Narrenschiff to a metaphysical tradition. In the centre of the woodcut there is the female maiden Justice in a frontal angle holding the «Richtschwert» (execution's sword), but sitting petrified on a chair like those used in German executions, called the "Richtstuhl» (execution seat) -with the fool as the executioner (Illustration I, Brant 1494, 71, Zanken und vor Gericht gehn). 


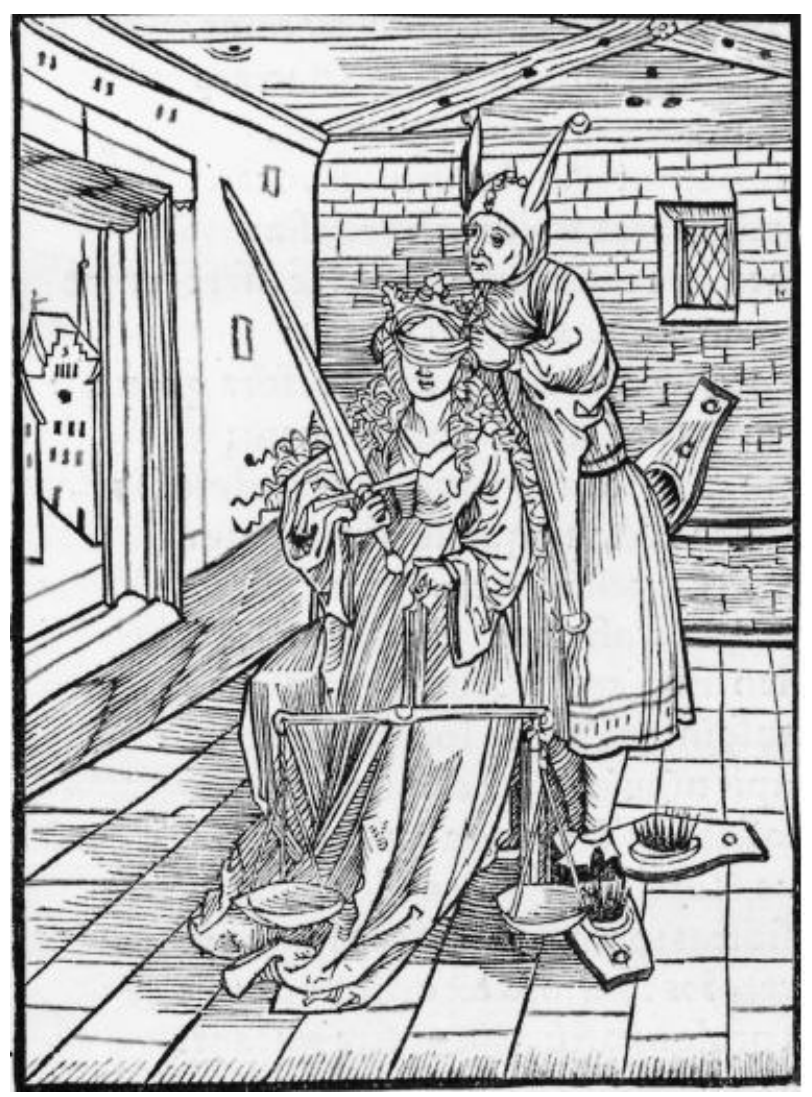

Accordingly, Justice becomes mingled with the judged one. Some scholars take this challenging picture as a virulent attack against contemporaneous legal procedures. Ernst von Möller (1905) was one of the first to explain the blindfold as a visualization of a contest between competing law systems. Academically trained jurists like Brant aimed to re-enforce Roman law instead of customary law, or to put it bluntly: instead of establishment folly. This was especially urgent in the Holy Roman Empire, which apparently was a collage of loosely interconnected courts and jurisdictions.

In the reframing process instigated by contemporaneous juristic discourse, the fool represents the corrupt law that mocks Justice. This setting is reminiscent of Christ being mocked by his guards after having been captured in the Gethsemane Garden, as Adriano Prosperi explains: "The rapid success of the figure of the blindfolded goddess was influenced by familiarity with the image of the Christ of the Passion» where "Justice took the place of the mocked Just One» (Prosperi 2018: 64). The 
motif already appears in the $14^{\text {th }}$ century in Italy and becomes popular again on the threshold between the Middle Ages and Renaissance, especially in Germany. Not least, Albrecht Dürer himself uses it in his "Die Kleine Passion» (Illustration II, «Small Passion», 1508-9).

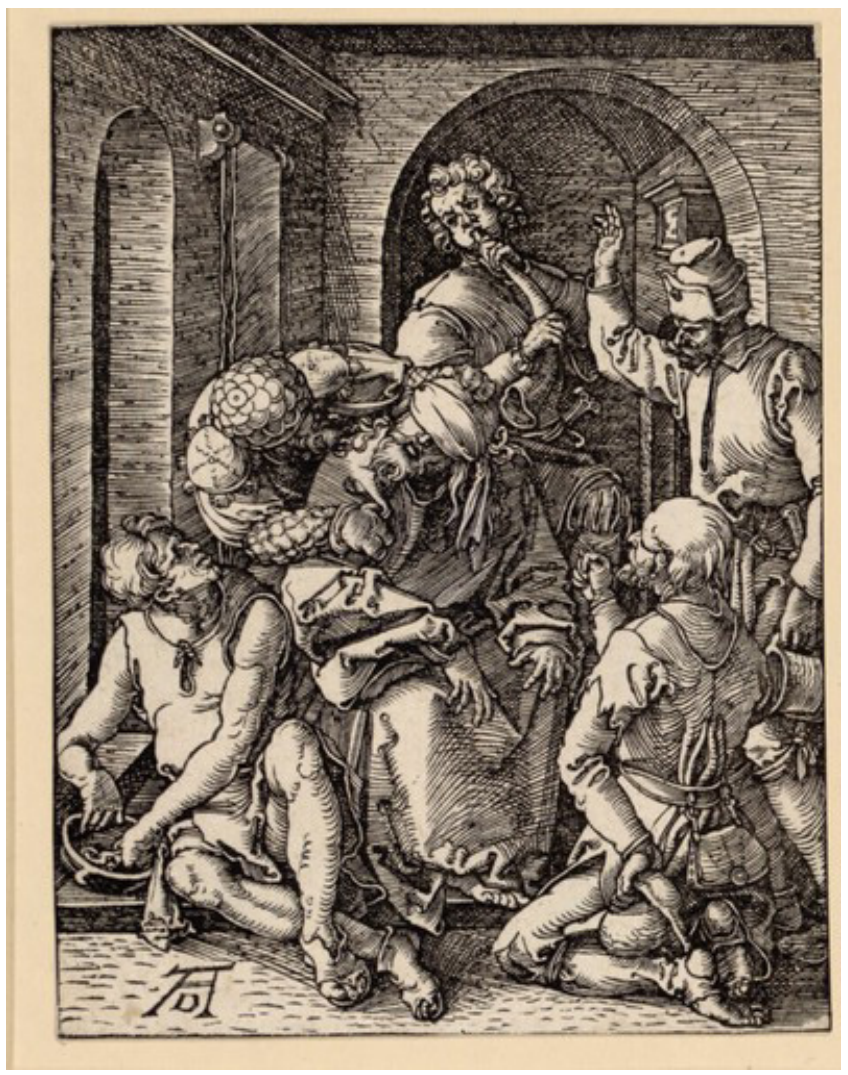

This $14^{\text {th }}$ sheet of Christ's Passion illustrates the following passage of Luke 22, 63-64: "The men who were guarding Jesus began mocking and beating him. They blindfolded him and demanded, 'Prophesy! Who hit you?'”.

In the Celestina the implications of Passion are corroborated by what follows: Pleberio's lament ends with "in hac lachrimarum valle» (Rojas 2011: 347), a quote from the Salve Regina. Thus, Pleberio is referring to Christ's mother, who sometimes becomes conflated with the figure of Ecclesia to represent the magnificence of the Catholic church. This recalls the other oddity in Panofsky's register, Synagogue. 


\section{The case of Synagoga}

Synagoga appears in late medieval iconography as a counterpart of the church, as for example in the illuminations of the Liber Floridus by Lambert de Saint-Omer (c. 1448, fol.171v) where Christ holds the centre between Ecclesia and Synagoga. Accordingly, Christ seems to mediate between the old and the new faith. This is partially due to the embarrassing fact that a significant part of the Holy Book is Jewish in its origin - the Old Testament. It was the eminent church father Augustine (354-430) who tried to reconciliate the vetus testamentum velatum (the old "veiled» testament) with the novum testamentum revelatum (the new revealed testament) by claiming the presence of the Christian element grace within the natural, as yet unrevealed law of the Hebrew bible-thereby allowing Jews to participate in Christian communities, albeit in a subordinate position. Towards his propagandistic mission of this hierarchical social order, Augustine launches in his City of God two female allegories-one called Ecclesia, representing the virtuous, the spiritual, in short, the City of Grace; the other called Synagoga, representing the transient, the carnal and therefore potentially vicious City of Natural Law (Augustine: Book $15,2)$. In the processes of social mobility and struggles of inclusion and exclusion on the threshold between the Middle Ages and Renaissance, these allegories are revisited. The most prominent depiction of the unequal «sisters» Ecclesia and Synagoga was located at the so-called Portal of the Virgin, the South transept, of the Strasbourg Cathedral (Illustration III, now located in the Museum of Notre Dame; <https://commons.wikimedia.org/wiki/user:Edelseider>).

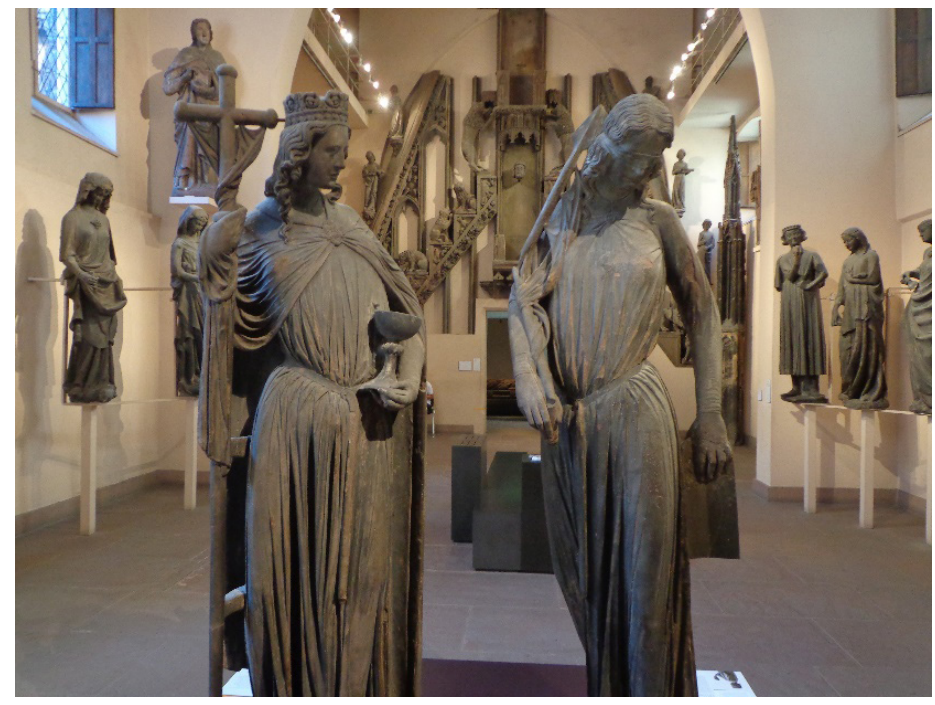


Ecclesia embodies the attributes and the posture of the ancient deities Nike, Athena or Victoria-including the Crown, the Scepter (a chalice) and her upright head position; Synagoga assumes some of the features of ancient Fortuna: her body seems to slump down in a resigned posture, her head falls on her breast with the eyes blindfolded, which are often corroborated by a broken crown at her feet and-in this example-by the broken lance.

But what made Augustine pick these allegories? In fact, he must have known the Hebrew holy text quite well, because the antagonist "sisters» Ecclesia and Synagoga are based on their earlier harbingers, Sara and Hagar. They owe their semantic strength to a pathosformel (cf. Warburg 1905) in an almost literal sense: in the Ketuvim ("Writings»), book five of the Hebrew Bible, there is a highly expressive narration called the "Book of Lamentations", which is traditionally ascribed to Jeremiah. This poem mourns the destruction of the city and the temple of Jerusalem. In the text, Jerusalem is metaphorized through Abraham's wife Sara in opposition to Hagar, her female handmaiden. Sara seemed to be sterile and therefore she obliged Hagar to sleep with Abraham and bear a child to the patriarch. Hagar did give birth to a son, but due to the cruel treatment of the patriarchal arch-parents she fled to the desert. Sara had her own son at the age of ninety and Hagar resumed her subordinate position.

In medieval Europe, Sara's antipode Hagar was adopted to assign to Jews their subordinate place in Christian communities; there, Ecclesia embodies the positive traits of Sara, whereas Synagoga refers to Hagar as an image for Judaism persisting in old Mosaic law, blind to the Truth (cf. Rowe 2011). Panofsky describes Hagar's metamorphosis towards the blind representations of Fortune, Death and Night, which «replaced the figure merely 'plunging into darkness' by a blindfold one». (Panofsky 1982: 111).

\section{Superimposed religion in the tragicomedia's afterthoughts}

Now, the young maiden plunging into darkness brings us back to Melibea. Obviously, at the time of the Celestina's publication, the question of genuine faith gained new momentum, irrespective of our appraisal of Fernando de Rojas' own status as converso. This becomes all the more evident in the concluding verses of the tragicomedia, which now explicitly recall Luke's narration of Christ's passion immediately following the passage quoted above: «[...] Amemos a Aquel que espinas y lanza, / azotes y clavos su sangre vertieron. / Los falsos judíos su haz escupieron,/ vinagre con hiel fue su potación;/ por que nos lleve con el buen ladrón/ de dos que a sus santos lados pusieron.» (Rojas 2011: 349). Thus, in these afterthoughts the story line of passion, crime and fraud is shaded by Chris- 
tian propaganda. Given the fact that religious discourse is conspicuously absent in the overall plot, there are two explanations for this "concluye el autor...»: either it serves as a cover-up to distract the Inquisition from its immoral content, or as an invitation to construe it as an allegory of the contemporaneous victorious crusade of the Reconquista: towards a uniform Catholic value system establishing a foothold. In such a reading Pleberio's lament over Melibea's death refers to the downfall of Sepharad (and with it the converso culture in Spain).

But there is an alternative explanation for the prominence of the two allegories in late medieval art, with regard to the ascertainment of judicial truth: Ecclesia and Synagoga embody the innocent and guilty parties in court, which was held in front of the church under the arch where the allegories were located (Weis 1947: 65-80). This brings us back to Justitia and a possible link to the discussions of old and new law in contemporaneous Germany and France.

To trace intermedial affinities let me briefly elaborate on collaborations within the early European print market.

\section{The ship of fools harboring in Spain}

As later Early Modern imageries suggest, the Celestina was considered as a text belonging to the same vein as the Narrenschiff, the picaresque, since the frontispiece of the Picara Justina (1605), where Celestina appears together with other picaresque outcasts in a ship not only resembles the earlier Retrato de la Lozana andaluza (1528), in fact both etchings seem to be replicates of the German satire. ${ }^{6}$ And just like the Celestina, the Narrenschiff experiences quite an intricate editorial fate: not only is it one of the most successful German texts of all times, but its 1501 Latin version by Jakob Locher, Stultifera navis, attained an even wider distribution, albeit in different forms. To complicate the history of its reception in other European countries even more, we also must take into account its two elaborations by Jodocus Badius Ascensius, the Stultiferae naves (1501) and the Navis stultifera (1505). These two publications represent a vast supplement and a free adaptation of Locher's Latin text, sometimes in combination: «Badius's texts are not translations at all, but one of them, the Navis stultifera, often masqueraded as one, and the other, the Stultiferae naves, had been, he claimed, written in order to be translated» (White 2014: 22).

For a possible intertextual relationship between these northern writings and the Celestina, Friedrich Biel, alias Fadrique de Basilea, is a crucial figure. Biel is one of many young Northern craftsmen participating in the «printing revolution» (Eisenstein 1983). He learned the technology in Mi- 
chael Wennsler's shop at Basel to later try his luck in Burgos, where he set up the first printing press (Pérez 2011: 54). Around 1500, Biel published the version of the comedia Celestina, which was long held to be the oldest version of the text and is famous for its woodcuts. Some scholars argue that these illustrations are inspired by northern editions of the comedies by Terence that were very popular in humanist circles, such as the one Jodocus Badius elaborated in the printing shop of his father-in-law Johann Trechsel at Lyon (Canet 2016: 96). Badius would later take over the business and extend it to become an important trading center between French, German and Italian humanism.

Therefore, it is noteworthy that in the same year as the Celestina, Biel also published in Burgos Badius' Stultiferae naves, a supplement meant to interact with Brant's text and also a warning against the fallacious impact of the five senses, which are depicted as young female passengers in a ship surrounded by fools. ? The Burgos edition of Badius' "patchwork satire» (White 2014: 33) is the only Spanish version of his vast publications and was bound together with other texts, but today the overall volumen facticio no longer exists. Julián Martín Abad's catalogue of the incunabula of the Biblioteca Nacional de Madrid indicates a compilation together with another Northern text, since it lists a «segundo ejemplar perteneciente a una edición de Lyon, 1498" (Abad XXVII). This might be the edition of Locher's Latin translation Stultifera Navis edited by Jacques Sacon', but this question cannot be settled for once. Remarkably, our commentator of the Celestina quotes from Locher's text, most probably from the incunabula I mention (CC 2002: 136). ${ }^{9}$ What remains evident, though, is the close network of German printers in Spain, like Biel, with northern humanism. One of its centers was Basel with its printing shops where Brant's Narrenschiff was published in 1497-fomented by the activities related to the university, which was founded in 1460 by Pope Pius II. Before he became head of the Catholic church, born Enea Silvio Piccolomini served as poeta laureatus at the court of the Holy Roman Emperor Frederick III in Vienna, where he authored the aforementioned Historia de duobus amantibus (around 1444). As Ines Ravasini points out, this quite famous erotic novel can be regarded as one of Celestina's sources (Ravasini 2003).

7.- As Duhl (2007) shows, the published version of the text is Jehan Droyn's translation «la nef des folles» (ca. 1498)»; obviously Badius intended the Latin text as a blueprint for translation (White 2014).

8.- Another possibility would be Badius' publication of Terentius Afer, Publius: Comoediae. Lyon: Jean Pivard, 17.III.1498.

9.- Here the editors of the CC who have my full admiration for their extraordinary achievement, must be mistaken: they use the title of Badius' free adaptation (Navis stultifera instead of Stultifera navis) in an edition (Paris: Marnef) that according to my knowledge only was in print in 1505 and does not use the quote translated by Locher. I gratefully owe this intertextual discovery to Snow 2004: 189. 
Interestingly, in 1496 the Historia was translated into Spanish and published in Salamanca with the same font as Nebrija's Gramática Castellana from 1492 (cf. Incunabula Short Title Catalogue in the British library). The Estoria muy verdadera de Eurialo, franco, y Lucrecia, senesa-as the anonymous translator titled the Historia-was bound together with the Spanish version of Piccolomini's De remedio amoris, along with a biography of the later pope, and a collection of his Sentencias. Today only one corrupt copy of this volume is left at the library of Ajuda in Portugal, where all parts except the Estoria itself are missing.

Fortunately, we have a meticulous description of the original volume by the German book historian Konrad Ernst who lists the Incipit and Explicit of the different parts in the Gesamtkatalog der Wiegendrucke and a reconstruction of the text (see Algaba Pacios 2016 and <https://gesamtkatalogderwiegendrucke.de/docs/M33576.htm>, 02.06.2021).

Algaba Pacios convincingly argues that the Sentencias y proverbios... are not a text that Piccolomini himself intended for publication but rather a selection of his aphorisms, mostly taken from his correspondences and compiled by Bartolomé Sacchi di Platina together with the Vita Pii II, thus the (translated) biography also mentioned in Ernst's entry. (Algaba Pacios 2016: 230 sig.; 246). We do not know of the other aphorisms collected in this final part of the overall volume that was printed in Salamanca in 1496-but interestingly, the very last of Piccolomini's alleged sentencias echoes the topic of Justitia's emblem in the Narrenschiff, for it clearly refers to the realm of Justice: "Los pleytean// tes son las aves / el auditorio la hera / el juez la red / los abogados.//» (see Algaba Pacios 2016: 239).

Thus, both texts caution against litigation in court, since lawyers create trouble (and costs) for the involved parties. In the context of a possible relation between the Estoria, the Narrenschiff and the Celestina, this coincidence is remarkable because in the period Salamanca was the breeding ground for Spanish jurists. The prioritizing of the legal faculty follows the model of Italian universities, which concentrated on jurisprudence and medicine and virtually disregarded theology-in marked distinction to northern universities (cf. Kagan 1974). Then again, Salamanca and Spanish university culture as a whole was ill-reputed for its deplorable philological quality. This is where Antonio de Nebrija comes in again. The Italian-trained converso saw his mission as bringing humanism to his alma mater. To this purpose he not only wrote a famous introduction to Latin grammar and literature, the Introductiones latinae (alias: Recognitio), but also the famous Grammática castellana (1492).

Yet as the introduction to this first vernacular grammar shows, Nebrija was no ivory-tower-scholar: "Siempre la lengua fue compañera del imperio». And indeed, his proposition to use philological education as an instrument of power gained him the support of Queen Isabel, in turn enabling him to publish widely. Obviously, Nebrija also played a crucial 
role in the printing business of (Northern) Spain. He entertained relationships with the aforementioned Fadrique Biel in Burgos, who printed his Introductiones latinae in 1493 and his Muestra de las antigüedades de España around the same time as the Stultiferae navis and the Celestina. ${ }^{10}$ Furthermore, Nebrija seems to have had his own printing press in Salamanca, an activity not compatible with his university position as First Chair of Grammar and therefore kept secret. ${ }^{11}$ In fact, Estoria muy verdadera most likely was the product of Nebrija's print shop. The elegant Latin prose of Piccolomini's original turns the love story into an attractive tool for the university's educational program, bolstered as it was by the more doctrinal De remedio amoris illiciti and by the fact that its author became pope. ${ }^{12}$ Thus, translations of these texts would be a valuable classroom enterprise.

And surely the quotes referring to the realm of justice must have met the interest of Nebrija, because he wrote a legal dictionary which he first entitled Aenigmata iuris civilis. The text obviously represents the hermeneutic endeavor of the philologist Nebrija in purging abridged quotes in the Digest of Roman law, much in the vein of Lorenzo Valla's critique of contemporaneous legal discourse (Perona 1991: 191). In the words of a legal historian, the Diccionario de derecho civil'13 (as the text was called from its second edition on) represents "Nebrija's definition of the legal enigma as a paradox occasioned by the failure to attend to the literary source from which a rule is derived» (Goodrich 2010: 85).

\section{From allegorical to metaphorical blindness}

Nebrija's approach to the main sources of legal studies can be linked to the Celestina: At the intersection of the "primitiva comedia" and the extended tragicomedia, there is another quite surprising monologue -Calisto's complaint about the inequity of justice. ${ }^{14}$ In this soliloquy, the lovesick protagonist starts out with an accusation against the judge who did not fulfill his duty with respect to his seigneur, Calisto's father: «iOh cruel

10.- The printer's colophon in the mentioned editions reads 1499, but book historians assume that Friedrich Biel used it during a period from 1499 to 1502. For further information see Canet 2016 and White 2014.

11.- For further information on Nebrija's alleged printing activities, see Pérez 2014: 51 (incl. fn. 27 and 28).

12.- The Latin text is a paraphrase of Ovid's Remedia amoris and edited in the correspondence of the later pope to his pupil Johannes Tröster who himself composed a Remedia (cf. Wolkan 1912).

13.- The volume also contained the anonymous Vocabulario utriusque iuris ((Esparza Torres/ Niederehe 1999: 28).

14.- For an analysis of the legal implications of Calisto's monologue and the impact of the law school in Salamanca, see Baranda 2003. 
juez, y qué mal pago me has dado del pan que de mi padre comiste! Yo pensaba que pudiera con tu favor matar mil hombres sin temor de castigo, jinicuo falsario, perseguidor de verdad, hombre de bajo suelo!» (Rojas 2011: 278-279). So far, this sounds like an apology for despotism. The annotator of the Celestina comentada leaves no doubt about the facts of the case: "Y ansi este agora se quexa de este juez llamandolo cruel por ventura por aver hecho buena justicia y esto nos quiso dar a entender nuestro author" (CC 2002: 407). A discernment that seemingly begins to dawn on our protagonist: after further elaborating on his own privileged status and pondering the legal capacity of his delinquent (and therefore executed) servants, all of a sudden Calisto seems to consider justice's reach and rules: "¿No ves que por ejecutar justicia no había de mirar amistad ni deudo ni crianza? ¿No miras que la ley tiene que ser igual a todos?» (Rojas 2011: 280). Again, the Celestina comentada emphasizes the universality of this idea quoting extensively from the Digest and pointing out: «Y por esta causa dize aqui nuestro author que la lei a de ser igual a todos, porque si con los hombres ricos e proserpos se usasse de otra manera que con los pobres seria las leies como dize Valerio Maximo [...] que las comparava a las telarañas [...]» (CC 2002: 416).

Calisto's inconsistent monologue combines feudal privileges and classical principles, in other words two competing law systems - customary law and Roman law. If we take into account that Calisto is not the most reliable and astute character, we cannot be sure of the veracity of his final appraisal. Rather, his soliloquy illustrates a comical misreading or an enigmatic paradox.

Equity is a codeword for the principles of Roman law, as the annotator of the $16^{\text {th }}$ century repeatedly shows (CC 2002: 412, 416 sig.). His insistence on this universal value highlight the ironic elaboration of juridic discourse even more. Its prominence in the literary riddle of the Celestina therefore effectively reflects contemporaneous academic discussions. The statement that everyone is equal before the law is a recurring claim expressed by three main characters-Celestina, Calisto and Pleberio. All three protagonists invoke it in a moment of (ultimate) loss which they experience as a result of their own blindness: Celestina is blinded by her avarice and tries to fool her partners in crime, Sempronio and Pármeno; Calisto is blinded by mad love and foolishly takes his feudal privileges for granted; Pleberio is blinded by his own commercial activities and foolishly ignores the hazardous condition of his adult daughter.

All these misconceptions point to changing economies and power relations on the threshold of early modern times, when longstanding social bonds and longstanding legal arrangements likewise lost validity. An emerging urban bourgeoisie tries to supersede traditional hierarchies represented by feudal seigneurs. At the same time, the modernization project of the Reyes Católicos was fueled by their hegemonical efforts 
and thus constantly threatened by competing aristocratic dynasties. One measure of appeasement was the creation of a common enemy, the fake converted, that is the heretic sticking to the old faith within the Christian community.

Still, many landed gentry refused their allegiance to the crown and insisted on their unrestricted power in local administration and courts. This is reflected by the coexistence of three competing legal corpora in Spain: «La solución fue considerar el derecho romano como ius commune para las cosas temporales; el canónico como ius commune para las cosas espirituales; y el derecho local y consuetudinario como, una suerte o clase de derecho especial [...]» (Ruiz-Capillas 2008: 333).

\section{The blind spots of absolutist humanism}

In this process of change, the University of Salamanca took on a crucial role, since many of its graduates became letrados in the newly built administrative apparatus of the Reyes Católicos. But gradually the alliance between urban humanism and the royals lost its momentum and was supplanted by a more conservative form of erudition. In this development, Cardinal Jiménez de Cisneros, the confessor and counselor of Queen Isabel, introduced his rather absolutist version of humanism. One of the stepping stones on his way to becoming a political and spiritual leader was the founding of the University of Alcalá, where he gathered eminent scholars for his major project, the Complutensian Polyglot Bible.

On a more modest scale, Antonio de Nebrija had much earlier launched his studies of the holy scriptures and, due to his profound erudition in Latin, Greek and Hebrew, was surely one of the scholars of the entire Iberian Peninsula most entitled to do so. But Nebrija met serious obstacles: in 1504, the Great Inquisitor Diego de Deza confiscated his texts on the Bible - and only due to the fact that Cardinal Cisneros followed Deza as Inquisitor General were the proceedings against Nebrija suspended: apparently, Cardinal Cisneros shared Nebrija's humanist approach for a better understanding of the Bible.

However, the two advisors of Queen Isabel had quite a different concept of humanism in mind. Cisneros founded "his» University of Alcalá as a counter model of the one in Salamanca. He explicitly renounced the formation of a faculty of law and established one for theology instead (cf. Kagan 1974). But it is in the Bible project itself where the differences of ideas between Cisneros and Nebrija become most evident. Nebrija conceived philological scrutiny as a path towards cultural translation and as such towards interpretation. Cisneros pursued the much more conservative aim of a linguistically correct text conforming to orthodox Catholic views. Nebrija did not contradict orthodoxy, but as an erudite conversant 
in different languages and cultures he most likely favored an ideal of convivencia and a culture of vivid scholarly debate. Under the augury of Erasmism and Lutheranism such ideas became more and more suspicious. From this point of view, one could sharpen Nebrija's lemma to «Siempre la religión y la lengua fueron compañeras del imperio»...

This leads me to suggest that the conflict-ridden historical situation had its impact on the Celestina, especially on its transformation from comedia to tragicomedia, since Calisto's soliloquy, parts of Melibea's monologue and the conclusion of the author are amendments of the latter versions. Perhaps the disguise of comedia constitutes a sort of refuge for acting out the tensions between old and new world views-albeit with the new appearing old.

To conclude: the Celestina could have originated in Salamanca's law student circles as a playful patchwork project mingling successful European texts such as the Historia de duobus amantibus and the Narrenschiff (and of course, all the other classical sources and juridical compilations the CC mentions) with Fernando de Rojas as the mastermind of this exercise in quodlibet, thereby resurrecting the reach of Roman law. Under the increasing significance of an orthodox Catholic ideology, it later had to be revised in terms of Christian ethics. In fact, also the Celestina Comentada appears to be a fixation of a moralistic rigorism that tries to neglect or even eliminate the ludic elements that turn the intertextual network into a literary masterpiece. Seen this way, the Celestina represents a unique paradoxical intervention between the poles of a Nebrija and a Cisneros, open for further philological scrutiny. 


\section{Works Cited}

Anón, Celestina comentada, eds. Luise Fothergill-Payne, Enrique Fernández Rivera and Peter Fothergill-Payne, Salamanca: Ediciones Universidad 2002.

Algaba Pacios, Nieves (2016), Enea Silvio Piccolomini en España. Con la edición del "Tratado de la miseria de los cortesanos". (Sevilla, Cromberger, 1520), Madrid: Universidad Complutense, Tesis Doctoral. <https:// eprints.ucm.es/id/eprint/40085/1/T37994.pdf>.

BARANDA, Consolación (2003), "Cambio social en La Celestina y las ideas jurídico-políticas en la Universidad de Salamanca.», in El Mundo social y cultural de la Celestina. Actas del congreso internacional, Universidad de Navarra, junio, 2001, eds. Ignacio Arellano and Jesús M. Usunáriz, Madrid: Iberoamericana/Vervuert, pp. 9-25. <https://doi-org.uaccess. univie.ac.at/10.31819/9783964566102-002>.

Bataillon, Marcel (1961), La Célestine selon Fernando de Rojas, Paris: Marcel Didier.

-(1966), Erasmo y España. Estudios sobre la historia espiritual del siglo XVI, México-Madrid-Buenos Aires.

BenKe, Nikolaus (2012), "On the Roman father's right to kill his adulterous daughter", The History of the family, 17.3, pp. 284-308. <https://doiorg.uaccess.univie.ac.at/10.1080/1081602X.2012.695940>.

Canet Vallés, José Luis (2008), «La Celestina en la 'contienda' intelectual y universitaria de principios del siglo XvI.»Celestinesca, 32, pp. 85-108. $<$ DOI:10.7203/Celestinesca.32.20109>.

- (2016), «Reflexiones sobre el libro ilustrado del impresor Fadrique Biel de Basilea», Revista de poética medieval, 30, pp. 81-104. <DOI: https:// doi.org/10.37536/RPM.2016.30.0.50219>.

- (2017), "The Early Editions and the Authorship of Celestina», in A Companion to Celestina. The Renaissance Society of America Texts and Studies 9, ed. Enrique Fernandez, Leiden: Brill, pp. 21-41. <DOI: https://doi-org.uaccess.univie.ac.at/10.1163/9789004349322_003>.

DuHL, Olga Anna (2007), "Vernacular Translation and the Sins of the Tongue: From Brant's «Stultifera Navis» (1494) to Droyn's "La Nef des folles» (c. 1498)», Fifteenth Century Studies; 32, pp. 53-67. $<$ https://uaccess.univie.ac.at/login?url=https://www-proquestcom.uaccess.univie.ac.at/scholarly-journals/vernacular-translation-sins-tongue-brants/docview/222335856/se-2? accountid=14682 > .

EIsEnstein, Elisabeth (1983), The Printing Revolution in Early Modern Europe, Cambridge University Press.

Esparza Torres, Miguel Angel and Niederehe, Hans-Josef (1999), Bibliografia Nebrisense. Las obras completes del humanista Antonio de Nebrija desde 1481 hasta nuestros días, Amsterdam: John Benjamins Publish- 
ing. <http://search-ebscohost-com.uaccess.univie.ac.at/login.aspx?direct $=$ true $\& \mathrm{db}=$ nlebk\&AN=368954\&site $=$ ehost-live $>$.

Goodrich, Peter (2010), «Legal Enigmas-Antonio de Nebrija, The Da Vinci Code and the Emendation of Law», Oxford Journal of Legal Studies, 30,1, pp. 71-99. <DOI: 10.1 093/ojls/gqqOO 1>.

IGLESIAS, Yolanda (2015), "Implicaciones legales de las seis muertes en La Celestina: Un acercamiento histórico-literario.» Romance Quarterly 62.2, pp. 59-70. <DOI: 10.1080/08831157.2015.998595>.

Kagan, Richard L. (1974), Students and Society in Early Modern Spain, Baltimore: Johns Hopkins University Press, 1974. <DOI:10.1353/ book.67888>.

Lacarra Lanz, Eukene (2007), "La muerte irredenta de Melibea». Proceedings of the International Symposium 1502-2002: Five Hundred Years of Fernando de Rojas" "Tragicomedia de Calisto y Melibea" (18-19 October 2002, Department of Spanish and Portuguese, Indiana University, Bloomington). Ed. and intro. Juan Carlos Conde. New York: Hispanic Seminary of Medieval Studies, pp. 173-208. <https://www.academia. edu/24925004/La_muerte_irredenta_de_Melibea>.

Leaños, Jaime (2007), Piccolomini en Iberia influencias italianas en el génesis de la literatura sentimental española, Potomac, Md. Scripta Humanistica $<$ www.scriptahumanistica.com> \# 159.

Matos, Kevin (2018), «De Lucrecia a Melibea: la concepción del erotismo femenino en la Historia de duobus amantibus de Piccolomini y en la Tragicomedia de Calisto y Melibea de Rojas", in Celestinesca, 42, pp. 189-224. <DOI: 10.7203/Celestinesca.42.20221>.

MölleR, Ernst von (1905), "Die Augenbinde der Justitia."Zeitschrift für christliche Kunst. XVIII. 4. (Düsseldorf 1905): coll. 107-122, 141-152.

Panofsky, Erwin (1982), Studies in Iconology: Humanistic Themes in the Art of the Renaissance. Chicago: University Press.

Pérez Fernández, José María (2014), "Translation, Sermo Communis, and the Book Trade", in Translation and the Book Trade in Early Modern Europe, eds. José María Pérez Fernánde. <https://doi.org/10.1017/ CBO9781139942393.003>.

Perona, José (1991), "Latina uocabula ex iure ciuili in uoces hispanienses interpretata. II,1, de Elio Antonio de Nebrija», in Cahiers d'études hispaniques médiévales, 16,1, pp. 189-65. <DOI: 10.3406/cehm.1991.966>.

Piccolomini, Eneas Silvio (2001), «Estoria muy verdadera de dos amantes, Euríalo franco y Lucrecia senesa», ed. Ines Ravasani, in Tratados de amor en el entorno de Celestina (Siglos XV-XVI), eds. Pedro Cátedra et al., Madrid, Sociedad Estatal España Nuevo Milenio, pp. 161-217.<https:// dialnet.unirioja.es/servlet/autor?codigo $=549411>$.

Prosperi, Adriano (2018), Justice Blindfolded: The Historical Course of an Image. Leiden: Brill. <https://doi.org/10.1163/9789004368675_001>. 
RAVASINI, Ines (2003), Estoria muy verdadera de dos amantes. Traduzione castigliana anonima del XV secolo, Rome: Bagatto Libri.

Rojas, Fernando de (2011), La Celestina. Tragicomedia de Calisto y Melibea, eds. Francisco J. Lobera, Guillermo Serés, Paloma Díaz-Mas, Carlos Mota, Íñigo Ruiz Arzálluz and Francisco Rico, Madrid, RAE.

Rowe, Nina (2011), The Jew, the Cathedral and the Medieval City: Synagoga and Ecclesia in the Thirteenth Century. Cambridge, UK: University Press $<$ www.cambridge.org/9780521197441>.

Ruiz-Capillas, Miguel Angel Jusdado (2008), "Ius Commune y Common Law.» Cuadernos de Historia del Derecho 15, pp. 327-344.<http:// search-ebscohost-com.uaccess.univie.ac.at/login. aspx?direct=true\&d$b=30 h \& A N=43607893 \&$ site $=$ ehost-live $>$.

SCHLICKERS, Sabine (2014), "Cherchez la femme: Genealogie und Entwicklung der spanischen novela picaresca" in LiLi, Zeitschrift für Literaturwissenschaft und Linguistik, 175,44, pp. 49-64. <https://doi-org.uaccess. univie.ac.at/10.1007/BF03379984>.

Serés, Guillermo (2011), "La obra y los autores del la 'comedia' a la 'tragicomedia'» in La Celestina, pp. 361-401.

Snow, Joseph T. (2004), "Celestina Examined: A View from the Sixteenth Century» in La corónica: A Journal of Medieval Hispanic Languages, Literatures, and Cultures, 33,1, pp. 181-196.<https://doi.org/10.1353/ cor.2004.0037>.

Sullivan, Henry W. (1976), "Moral Probabilism and Casuistry in Spain during the Counter Reformation", Tirso de Molina and The Drama of the Counter Reformation. Amsterdam: Rodopi, pp. 40-51.

Weis, Adolf (1947), Die „Synagoga" am Münster zu Strassburg, Das Münster, pp. 65-80.

White, Paul (2014), «Marketing Adaptations of the Ship of Fools: The Stultiferae naves (1501) and Navis stultifera (1505) of Jodocus Badius Ascensius» in Translation and the Book Trade in Early Modern Europe, eds. José María Pérez Fernández and Edward Wilson-Lee, Cambridge: University Press. <https://doi.org/10.1017/CBO9781139942393.002>.

Wolkan, Rudolf (ed.) (1912), Der Briefwechsel des Eneas Silvius Piccolomini: Abt. 2. Briefe als Priester und als Bischof von Triest«, Fontes rerum Austriacarum, 67, pp. 33-39. 